The Case against Perfection 



\title{
The Case against Perfection
}

\author{
ETHICS IN THE AGE OF \\ GENETIC ENGINEERING
}

\section{Michael J. Sandel}

THE BELKNAP PRESS OF

HARVARD UNIVERSITY PRESS

Cambridge, Massachusetts, and London, England 
Copyright $(\subseteq 2007$ by Michael J. Sandel

All Rights Reserved

Printed in the United States of America

Library of Congress Cataloging-in-Publication Data

Sandel, Michael J.

The case against perfection : ethics in the age of genetic engineering / Michael J. Sandel.

p. $\mathrm{cm}$.

Includes bibliographical references and index.

ISBN-13: 978-o-674-o1927-o (alk. paper)

ISBN-10: o-674-01927-X (alk. paper)

1. Genetic engineering-Moral and ethical aspects. I. Title. $\mathrm{QH}_{43} 8.7 . \mathrm{S}_{2} 6342007$

$174^{\prime} .957-\mathrm{dc} 22 \quad 2006039327$ 
For Adam and Aaron 
